УДК 94(439)"1940":340.15

DOI: $10.24144 / 2523-4498.2(45) .2021 .247548$

\title{
NEIGHBOR CONNECTIONS AND CONTEMPORARY GROUPS IN A CLOSED SOCIETY, IN THE CITY OF HAJDÚDOROG
}

\author{
Sári Tamás \\ PhD student at the University of Debrecen, Faculty of Humanities, Doctoral School of History and Ethnography \\ Email: tamassari3@gmail.com
}

Hajdúdorog is a local closed society, so the religious separation, the Hajdu military past and the agricultural nature of the settlement provide a specific approach to ethnographic researches. In my doctoral research, which includes this article, family and neighborhood relations are analyzed in this settlement. The temporal focus of the research is the 1940s which is the earliest decade that can be researched with informants through interviews. This article pays attention to the neighborhood of Hajdúdorog and contemporary groups, so locality is a key concept. The research question concerns the content of the relationships. How did the relationships in the environment of the neighborhood and contemporary groups, manifest themselves in Hajdudorog in the 1940s? How did the above features affect this? The research was carried out within the framework of the ethnographic discipline. The article first presents the well-known works of the Hungarian ethnographic literature on the topic and then analyzes the empirical data. I applied the ethnographic method used in social disciplines to obtain empirical data. During the field work, I did in-depth interviews in Hajdudorog with locals, all older than 75 years. I reached the inteview subjects using the snowball method and the interviews took place in the interviewees' homes. The article examines the neighboring and contemporary groups separately. Based on the results it can be stated, that in Hajdúdorog the neighborly relations were daily. The tenths, the former special administrative units of the city, were still strong influencing factors in the development of relations in both groups, even during the researched period. The content of the neighborly relations was reflected in smaller household transactions, rental of tools, participation in pigslaughters (disznóvágás), assistance in fieldworks, special folk pastimes (tanyázás) which resulted in more intense relationships than with family relatives. The result of a closed society is that there was a closer relationship between those who lived within one part of the settlement than between relatives who lived in different parts of the settlement. In line with the above, the article seeks to contribute to the researches connected to locality. The subject of the article fits into the sociological neighborhood research category, such as Tönnies and Redfield's research and also fits into the neighborhood research of the Hungarian ethnography, which was also a base for this research. This work hopes to ultimately expand the row of Hajdudorog's literature. For further view, the article can encourage research that deals with a more detailed comparison of the role of the neighborhood and the role of neighbors and relatives in Hajdudorog during the period that was examined in this article.

Keywords: neighborhood, locality, Hajdúdorog.

Introduction and the formulation of the issue. Neighborhood relations are being examined in several aspects. Sociological tests shall examine the confidence in the neighbors, the frequency of meetings and the intensity of contacts, helpfulness and other areas [Giczi - Sik, 2009]. One of these issues is the helpfulness that Endre Sik refers to as household transactions and is specifically a general phenomenon in the community, that he is examining [Sik, 1991, p. 85-90]. The names of Ferdinand Tönnies [Tönnies, 1983] and Robert Redfield [Redfield, 1960a, 1960b] may be mentioned in connection with the sociological research on the neighborhood issue.

Neighborhood in the peasant society has often been built over several generations. The close relationships that they established came with many benefits [Fél - Hofer, 1969; Bődi, 1992, p. 429; Fél, 1993, p. 86]. It was important that they should be in good spirits, since as Morvay says, they are the witnesses of their neighbors' lives and the village's public opinion about the family was most influenced by the neighbor [Morvay, 1981, p. 177178]. As for the term witness to our life, it should be noted that the hardship, laziness was most closely observed by the neighbors and the mention was made of the mistress, if she thought it was necessary [Morvay, 1981, p. 177-178]. The neighbor relationships were mainly formed by the women, for example by renting household equipment to each other but also by framing each others' reputation. The subject has been handled by several authors [Penavin, 1981, p. 22, 153, 206; Morvay, 1956]. Örsi said that the local statutes gave the neighbors similar rights to these relatives but the priority was always given to the relative [Örsi, 1990, p. 108-109]. Intimacy in neighborhood relations had its limits and neighbors were not told about family problems and conflicts [Nagy Varga, 2000, p. 556]. One of the most important ethnical issues in the context of neighborhood is the role of local people but there is also extensive literature covering the definition of the neighbors, as well as helping one another and sharing a good time with the neighbors. So the question of the research is: how can these relations be described in a closed society, like Hajdúdorog in the 1940's?

Study objectives and research method. In the following, we will endeavor to examine the above in detail by using literature and empirical knowledge. The study seeks to contribute to social science work in relation to neighbors and contemporary groups within the framework of ethnical disciplines. The research site is Hajdúdorog in the 1940's. Regarding the methodology, in-depth interviews were collected of the empirical data, which I have collected among the local elderly over the age of 75 . This was done after reviewing the literature on other local societies and the municipality. The interviews were 
typically located on the premises of the data providers, who were accessed through the snowball sampling method and familiarity networks. This study was carried out using the relevant parts. After grouping, the information was collected by topic. In the following, there will be an ethnographic approach to neighbors and contemporary groups. After a review of the literature, I will analyze the recorded data in a similar structure.

Analysis of sources and literature. Generally, the neighborhood included a number of houses in a row, including the neighbors to the eye [Fél - Hofer, 1979, p. 6; Tárkány Szücs, 1981, p. 65; Örsi, 1990, p. 83, 87, 109; P. Madar, 1989, p. 40; Molnár, 1992, p. 70].

In Karcag, the land neighbors by touching borders can create a 5 to 10 houses neighborhood. The older the neighborhood connection was the stonger it got. In the 18th century, on Karcag, the deteriorating neigbourhood relations were called upon by the council (the city's leadership) [Örsi, 1990, p. 108-109]. Judit Morvay states the neighbor was everyone who lived on the same street line [Morvay, 1981, p. 177-178].

In the concept of A. Appadurai's locality concept, the connections and the context has a quite important role. The locality is created by the neighbors and is derived from the everyday practices of the neighbors, providing a framework for human actions [Appadurai, 1996].

Locality in the traditional society meant a sense of belonging and its members considered their traditions mandatory for themselves. Neighbors' contact had a community building role [Nagy Varga, 2000, p. 552].

Örsi mentioned, that a neighborhood is the smallest local group and that as an institution is more active, if the members of that group has familial relationship [Örsi, 1990, 109].

In terms of locality, Tárkány Szücs refers to broader areas such as the Hajdúság ${ }^{1}$, which was a separate area with its own administration, that they also preserved their unified culture for a long time even after the settlements' independence had been eradicated. Their various privileges have made them united people [Tárkány Szücs, 1981, p. 51-54].

László Szabó also talks about locality and neighborhood in relation to the jász people. Amongst jász people, the blood-based relationships were stronger than nemzet ${ }^{2}$ clan, army, extended family, small family [Szabó, 1982, p. 127].

The principle of locality and the impact of the native population must be highlighted when discussing neighborhood relations. The importance of this is also demonstrated by the term jöttment, who is a person not welcomed by the local people. For example in Varsány, who didn't belong to a clan was not considered to be a great person since they were not a local from the village, they called them by term, «jöttment ${ }^{3} »$ [Jávor, 1978, p. 306].

The village's control strongly regulated the behavior but in great trouble such as a burnt house or a fallen wagon,

\footnotetext{
${ }^{1}$ The area taken over by the hajdú people, after the 17 th-century hajdú resettlement which includes Hajdúdorog too.

${ }^{2}$ Nation, but here: in folklore: kinship, usually paternal, clan. [Ortutay, 1980] http://mek.niif.hu/02100/02115/html/3-2098.html

${ }^{3}$ Stranger who is not accepted by the locals.

${ }^{4}$ In the 19th and 20th centuries, the folk name of the Hungarian

peasantry of the basin-like areas from North of the Mátra and the Bükk
}

the whole village came to help instantly. Poverty was only taken into accountin the case of children's marriage, otherwise they helped the poor. - wrote Judit Morvay [Morvay, 1981, p. 177-183].

The neighborhood can also extend to neighboring settlements as Olga Penavin shows through Slavonian fraternity [Penavin, 1981, p. 22, 206] but there are also examples for this in the surroundings of Szécsény where palóc people ${ }^{4}$ live and also in the Greek Catholic neighboring villages [Palotay, 1931, p. 36; Sárvári, 1996, p. 212].

In addition to their endurance, the settlements of the moors around the River Dráva, the Danube and the Valkó helped their survival by not distinguishing between nationalities and having good relations with the inhabitants of the Croatian and Serbian villages [Penavin, 1981, p. 22].

When the family members settled close to each other, they instantly became the neighborhood of each other. This could be concluded from the fact that former records show one name repeatedly in a row of houses next to each other [Örsi, 1990, p. 83].

In fact, it can be shown, that a family name can be specifically linked to a part of the city. In connection with the social organization Julianna Örsi writes, that in Karcag, this can be clearly demonstrated by mapping the families of the data communicators [Örsi, 1990, p. 87]. It also led to the autonomy of certain parts of the city because certain parts were mainly populated by one kinship [Örsi, 1990, p. 109].

Neighborhood assistance and day-to-day contacts are a major topic, which is being processed by many ethnic studies covering a wide range of areas of assistance [Ballagi, 1850 II. p. 408; Fél - Hofer 1969, p. 174; Tárkány Szücs, 1981, p. 686].

Sociologist Endre Sik, in his paper on household connection systems writes, that the true homes of community life are the rural settlements based on Tönnies and Redfield. Sik also claims that there was no recorded household in the municipality of Vésztő who did not give or receive. Actually, he calls that a household transaction. The most common among the thirteen household transactions were caregiving, gifts, kóstoló ${ }^{5}$ and disznóölés ${ }^{6}$ but there are also numerous cases of repairs, assistance in building works, tool loans and help in job seeking [Sik, 1991, p. 85-90].

In the Slavonian world, fraternal friendships between Hungarian, Serbian and Croatian families meant, that they shared their experiences of building houses, dressing, eating, farming and also in the topic of family organization. as well [Penavin, 1981, p. 206].

Though in Karcag nowadays (1990) the neighborhood still has a strong role to play in helping and controlling [Örsi, 1990, p. 109].

mountains and the valley of Ipoly (to Ipolyság) [Ortutay, 1980] http://mek.niif.hu/02100/02115/html/4-394.htm

${ }^{5}$ folk custom: food sent out of kidness to the person(s) not attending the dinner on the occasion of a pig slaughter.

${ }^{6}$ slaughter and processing of a fattened pig to ensure annual household meat and fat reserves [Ortutay, 1980]

http://mek.niif.hu/02100/02115/html/1-1610.html 
As for the bokortanya ${ }^{1}$ (multiple homesteads close to each other forming a settlement), Mihály Márkus writes that they lived in close neighborly relationships, which often involved more responsibilities than family relationships [Márkus, 1943, p. 207].

Morvay writes that the neighbor mistress took care of the children, if they had work in the field [Morvay, 1981, p. $177-178]$.

A data collector interviewed by István Ternovácz, who was living in Temerini during the time of the banishing of the Hungarians of the Vajdaság, was asked how was their relationship with the bokortanya neighbors before the II. World War. He still remebered them by name. According to that data, the neighbors lived on very good terms which was supported by the fact that a Serbian saved one of their good cows when they should have been driven away by order [Ternovácz, 1996, p. 26].

The subject of tanyázás ${ }^{2}$ also has extensive literature. In fact, we are talking about relaxation and the satisfaction of spiritual needs that may have happened outside the gate after work, but also in the form of an all-day visit [Molnár, 1992, p. 63].

The neighborhood may also be described as a cultural unit due to the tanyázás and fonók ${ }^{3}$. These places later became the «children's playground community» as they lost cultural importance for socializing [Örsi, 1990, p. 109].

In Mihály Hoppál's work on communication systems, he also examined neighor visits. For neighbors the number of daily visits are high, few have given weekly or monthly responses but rare visits were also typical. By comparison, visitings were relatively balanced for relatives but most of them have nominated one or two visits per week. These recordings are from the 1970's but also from previous years data. The author concluded the dominance of the neighborhood against the family relatives. Also the role of the village community was increasing [Hoppál, 1970, p. 25-27].

A good example of a neighborly relationship is the sending of a taster, which many authors have described. Elizabeth Bödi also writes about the festive cake that they consumed during weddings and also had the name: kulcsoskalács in the Nagy-Alföld ${ }^{4}$ of Hungary, which was consumed in the course of a wedding. The priest, the teacher, the baker's family and some neighbors were sent from the freshly baked festive cake before the cake was eaten by the guests [Bödi, 1992, p. 428 - 429].

The homesteads of Szeged were mostly neighbors and this relationship was based on joint work and mutual assistance [Juhász, 1993, p. 133].

${ }^{1}$ small group of houses on the border, between arable lands [Ortutay, 1980] http://mek.niif.hu/02100/02115/html/5-397.html

${ }^{2}$ They spend time with each other, they visited each other.

${ }^{3}$ Weaving hemp lint in collaboration. the life of the spinning mills are characterized by games, the late-night fun of the youth, their dances and the ,prurient, luxuriant chants... or other scandalous naughtiness" [Ortutay, 1980] http://mek.niif.hu/02100/02115/html/2-405.html ${ }^{4}$ geographical area in Hungary: the Great planes of Hungary.

${ }^{5}$ The corn cobs are usually gathered at the house after harvesting. During this corn splitting process, they are cleaned of the leaf by acquaintances, neighbors and relatives, helping each other out, working together. Working together is a good opportunity to talk, tell stories, playful banters, singing and solving riddles. [Ortutay, 1980] http://mek.niif.hu/02100/02115/html/3-973.html

${ }^{6}$ Feather picking is the social work of adolescent and adult girls and women takes place in rented houses with the participation of those invited
At the beginning of the 19th century, people visited each other mostly during winter. In summer they visited each other on holidays only [Juhász, 1993, p. 133].

On Kecel, the people also had the neighborhood meetings at the beginning of the century, which were the occasions of kukoricafosztás ${ }^{5}$ and tollfosztás ${ }^{6}$. These also meant some fun besides work [Örsi, 1984, p. 842].

Morvay said, that the neighbors had been frequently visiting each other during winter. They spinned together and they had been advising each other [Morvay, 1981, p. 177 - 178].

The neighboring children played together and later they chose a bride within the street with their mother's consent [Morvay, 1981, p. 177 - 178].

Finally, it should be noted that the homestead people were not left alone, all the families belonged to the community where there were meetings, mutual assistance/help and the basis of this all was the neighborhood [Juhász, 1993, p. 131 - 142].

Contemporary groups in the literature. In different societies, there is a lot of evidence for age groups to form their own clusters. In this context, we are talking about gangs $^{7}$ in the peasant world. Have to mention the initiation rituals into these gangs and that there were smaller gangs forming amongst the youngsters. We also have to discuss the topics of the school age, $\mathrm{koma}^{8}$ and mátka ${ }^{9}$ connections and different age groups, that the gangs composition based upon.

A number of authors processed the world of gangrelated activities, which had not yet been separated by generation before the I. World War. The life within the gang had an educational role, which ended because later the gangs were formed by age groups and carried on their activities regarding their age [Csete 1993, p. 193; Vankóné Dudás, 1983, p. 59, 320].

László Szabó also writes about gangs in connection with the jász people. Szabó draws attention to the fact that locality was only characteristic of certain social groups, such as the youth who made a gangs based on the different parts of the village [Szabó 1982, p. 128].

The gangs on Kecel were present mostly before the I. World War. Typically the rich and the poor young men had separate gangs and the gangs were never interconnected [Örsi, 1984, p. 907 - 908].

The various events of the young boys ritual were usually linked to a remarkable day, where young people were initiated and became full members of the gang. There they were prepared for adult life [Viski, é.n, p. 396-406; Németh, 1966, p. 255-261; Németh, 1980, p. 431; Vasas -

during the winter. Feather picking, like all kaláka-type work, is both a common thing and a group activity with some fun. A striking feature is that only women can participate; when the lads are visiting on these occasions, it is usually involves traditional jokes. [Ortutay, 1980] http://mek.niif.hu/02100/02115/html/5-693.html

${ }^{7}$ It has several meanings, here: friendly community in folk society with specific characteristics (gang).

${ }^{8} \mathrm{~A}$ man or female friend who is usually in a close relationship with another man or woman due to a ritual. A koma is never related but $\rightarrow$ komaság often means a more personal, closer relationship than relatives. [Ortutay, 1980] http://mek.niif.hu/02100/02115/html/3-644.html

${ }^{9}$ choosen sweetheart, friend, generally means a close person (...) best girlfriend. [Ortutay, 1980] http://mek.niif.hu/02100/02115/html/31597.html 
Salamon, 1986, p. 174-176; Imreh, 1978, p. 232, 236; Tátrai, 1994].

Turning to the Lexicon of Hungarian Ethnography we can find the expression legénycéh, meaning the bachelor's guild, which is also known as the bachelor association, or the bachelor companionship, or the bachelor wreath. It is an organization which, could even have a written statute. These bachelor guild were typical in the Kisalföld, in the mining villages and the homestead lands of Felföld and Transylvania (Erdély). They were subordinated to the church and the city administration and their structure was hierarchical [Ortutay, 1980, p. 428].

If we are talking about young people, we cannot fail to mention the book of Zsuzsanna Tátra: Leányélet (Maiden life), in which we are talking about girls and bachelor initiations, age groups and spinning mills. Initiation was an important event for young people towards becoming grown ups. During initiations they went through serious and funny rituals and it was significant point in their life. After the initiation, they could decide more freely and start the period of looking for a life partner. We already talked a bit about age groups earlier and you can see that girls and boys were making friends within their age. They had different options depending on their age [Tátrai 1994, p. 11-12].

Spinning was a great opportunity to get to know each other and choose a partner. The girls were waiting for the boys in the fono and the girls also practiced magical tactics to help the boys arrive sooner. Upon their arrival, the girls greeted them with a singing and then they played various games [Tátrai, 1994, p. 90 - 96].

The younger group of gangs (bandák) are the little gangs, little friends (koma) after learning to walk, they quickly found their contemporaries on the street and spent their days playing without gender segregation [Fél - Hofer, 1969, p. 185].

As for the girls, cimborázás, komázás ${ }^{1}$ begins even before school, according to the village of Átány. Usually, 2-4 girls of similar age play together, they are together at school and after school as well [Fél, 1993, p. 73].

According to the streets and corners, they went to the school at the same time and they also played together during breaks. The villages had their own grassy playgrounds called pást [Nagy Varga, 2000, p. 550].

In Átány, the boys in one class called each other koma (friends), the girls called each other mátka (female friends). They chose a best friend from the gangs. The most important condition of belonging to a gang was residence. The neighborly relationship was so strong that it could even override the age difference [Fél - Hofer, 1969; Fél, 1993, p. 73].

After the school years, the gangs became even more intimate, they went to pubs together [Fél - Hofer, 1969, p. 186].

For bachelors, pubs and balls were important topics. In the pub, the lads of Jászkisér often drank more than they had, which was later offset by the fact that they had to steal from home [Csete, 1993, p. 198 - 201].

In Kecel, the gangs also differentiated according to wealth. Nagy Varga, 1984, p. 907]. Balázs Csete also mentioned the lives of bachelors and maidens in connection with the life of the Jászkisér children.
Regarding to adolescence, he describes their life by living in a stable and ganging. In adolescence, the boys sleep in the barn until marriage, which already means freedom for them. During this time, while studying with the elderly, they also learned their wisdom but also had fun with wine, dance and songs. Ganging (bandázás) on the other hand, should not be confused with homestead visits (tanyázás). In the latter, whole families go to the other and then vice versa and the former are always in the same barn [Csete, 1993, p. 193 - 198].

Mrs. Juli Dudás Vankó also talks about bachelor's life in her volume about the village of Galgamácsa. During the Advent period, the lads of Galgamácsa went to chant in groups of 15 to 20 people and before that the rehearsals were held in the stables. Like the boys, the girls went to chant too. After the chanting, they dressed nicely for the celebration and went to the midnight Mass [Vankóné Dudás, 1983, p. 320 - 324].

Characteristics of the research site - Hajdúdorog. Before analyzing the empirical data, we need to talk about Hajdúdorog, about the characteristics of the research site. The reason for the choice of location is the agricultural character, which was a general characteristic of the settlement. Being an agricultural city, impacted by the social isolation was a result from the religious difference compared to the neighboring cities. The basis of the religious difference between the settlements is that Hajdúdorog is the only Greek Catholic community among the reformed towns of the Hajdúság. Hajdúdorog not only maintained this religious separation, but also became the center of Greek Catholics in Hungary. According to the 1949 census, $86.4 \%$ of the population of the settlement was Greek Catholic, 7.2\% Roman Catholic and 5.3\% Reformed. In the two neighboring settlements, Hajdúnánás and Hajdúböszörmény, the proportions were reversed. The former is $85 \%$ Reformed, $10.8 \%$ Roman Catholic and only 2.0\% Greek Catholic. $81.9 \%$ of the latter were Reformed, 8.1\% Greek Catholic and 7.6\% Roman Catholic but the proportion of Reformed was also over $80 \%$ in Hajdúhadház and Hajdúszoboszló [Népszámlálás, 1949]. This separation gave rise to conflicts between the settlements and the locals of Hajdúdorog, who turned inwards. This provides a special medium for studying the topic. Also this is the historical shaping factor that determined the development of Hajdúdorog. Furthermore, according to István Balogh, there is no other society where farming and way of life have left such mark as in the Hajdúság area [Balogh, 1969].

The civil city center, the peasant village and the poor housing estate could be found in the settlement, together with the corresponding social strata. However, ethnic diversity cannot be said of the settlement, so this is not a significant shaping factor in the issue under consideration. According to the nationality ratios established on the basis of the mother tongue, in 1941 the population of the settlement was 99.2\% Hungarian and in 1949 the population was $99.9 \%$ Hungarian. The reality can be distorted mainly by Hungarian-speaking Gypsies. According to an 1893 census, $3.9 \%$ of the population were Gypsies but in the 1930 and 1933 censuses their proportion fell below $1 \%$ [Klinger, 1997, p. 51]. In connection with the family, it can be said that, from the end of the 19th

${ }^{1}$ Fellowship, friendship. Spending time with friends. 
century it was no longer the patriarchal but rather the elementary small family that was the dominant form. Despite the significant socio-economic changes, the predominantly agricultural society and ecclesiastical presence which was typical of the 1940s, the settlement retained its characteristic role.

Empirical data from Hajdúdorog: research results. In Hajdúdorog, for the 1930's and 1950's, the neighborly relations are typically described positively by the informants. They are largely unanimous in their view that these relationships have been better than they are today and are often even valued higher than their relatives in some respects, which will be discussed below. Help and passage to each others house were mentioned first and several explained that «people loved each other» in general. In a smaller street the whole street or a few houses in a row were thought as neighbors.

The manifestation of love was substantiated by the following:

"then we loved each other, my father got sick, the kids next door came, they said don't be sick Uncle Gyuri, poor kids offered to sleep with him, just for him to not stay sick anymore.» [DENIA: 4545/4].

And another informant, when her husband was taken as a soldier in October, at harvest time, was left alone with the fieldworks:

"There were a lot of potatoes, lots of corn. The strand of my hair stood in the sky like this is ... i didn't know what will happen this year. (...) but there was 15-20 of us harvesting the vegetables.» [DENIA: 4545/1].

Several of the interviewees mentioned visiting each others house, either under the term tanyázás or in other words.

"At that time, they went to each other a lot, because there was no TV, no radio, so to play cards, and I don't know, just to talk.» [DENIA: 4545].

There were those who said they visited each other and the mentioned activities like playing cards several times but they also mentioned conversation and mill game (malmozás). Assistance in slaughtering pigs and sending tastings were also mentioned as one of the embodiments of the neighborly relationship.

In the case of neighborhood assistance, I distinguish three topics. On one hand, we can talk about helping with fieldworks, on the other hand, lending money, and thirdly, borrowing all other smaller assets and activities that do not require more energy or bigger portion of time.

On the latter question, the answers were unanimous:

"Oh, the connection was very good there, they came to help when we needed something, and there we had very good water (...) the whole part came and took it, so the man really came together. (neighbors who worked nearby): And there we had fruit, there was strawberry, it was, they went to eat strawberry, and my mother brought them bread to eat with the fruit. So it was never like, that we didn't give if we could, you know.» [DENIA: 4545].

In addition, poorer neighbors lent each other food items such as peppers, fat, and so on.

With regard to the other two categories mentioned above, lending money and helping with earthworks, the situation is no longer so clear. Several said that neighborhood assistance extended to these as well but some recall that there was no cooperation in the field works. And for money, some respondents said there were stricter rules.

When it comes to money, the two types of opinions are:

"They borrowed money, yes. Those who had more money divided it with the other, people were not as envious as people are nowadays. They helped each other out if the other could.» [DENIA: 4545/4].

«Well, if you had to (money was also lent). But only by writing paper, like that.» [DENIA: 4545/3].

There are also two kinds of beliefs in field works:

"It was alfalfa, grain, wheat, and sorghum. We cut it down three times, we fed it to the cow, we didn't help the neighbors, everyone was after their own, it wasn't like we joined forces..» [DENIA: 4545/5].

"There were also times when one had only a cow and the other had one too, they put the cows together and plowed the land like that, it was like that. (husband: That was like that, of course, that was, okay, it does not belong here but on the market one cow farmers were with other one cow farmers and two cow farmers were with two cow farmers...) Well listen, even if you laugh at me for this, who had a cow, he could not plow with one but captured two and they did each other's lands, first the lands of one, then the lands of the other.» [DENIA: 4545].

Informants who argued that they did not help each other with their neighbors in the field work explained this with two thoughts. On one hand, there was not enough land that a large family could not cultivate, so this mechanism did not develop. On the other hand, who could have helped was also a matter of business, as the crop was ripe for everyone at the same time. The more emphatic opinion, however, was that they also helped each other in the field works. This could have been the case again when the rain came and the crop had to be harvested quickly. They were plowing each other alternately, like three or four farmers together. Furthermore, to harvest the corn and to carry sheaf were done first for one of them, then for the other. They also helped in case of an accident or if the neighbor had a weaker animal and could not plow for himself. They helped among the homestead farmers living further from the city, the one who had a horse and a chariot often gave a lift to his neighbor when he went into town.

"Only Mr. Szabados had a horse, he didn't always go to Nyiregyháza (certain homesteads who belonged to Hajdúdorog, were closer to other settlements than to Hajdudorog itself, as they were on the edge of the city), if he went, he said to come, that come and I'll give you a lift.» [DENIA: 4545/5].

Those who believed that people did not help each other in the field work, they also testify to a good neighborly relationship, including people paying attention to each other.

Among the questions about the neighbors, the following question was given a key role: Was the relationship with the relatives or the neighbors more intense? Of course, the answers did not narrow down to the evaluation of intensity. I was able to record the first thoughts that appeared after the parallelism of the relative and the neighbor. The answers tipped cautiously but in the direction of the neighbor. This answer was noticeably tipped in that direction due to the active daily contact, friendships and last but not least, the usefulness of the neighbor. 
«A good neighbor was better than a relative officially.» [DENIA: 4545/3].

The neighbor was always there for the man and the relative was either there or was not at all. Even if there were good relatives to the family, they might have lived far away. In Hajdúdorog, the northern homesteads could have been more than 10 kilometers from the city, so there was noone in the everyday life besides the homestead neighbor.

"The neighbor was so much better because he was close. When something wasn't there or we needed some help, the neighbour was next door. We should have come 16 kilometer to meet the family, it was further away.» [DENIA: 4545/4].

In helping, moderate standpoints also placed equal emphasis on relatives and on neighbors.

«So-so. If there was a slaughter of pigs, to clean, to reap, to harvest corn, then the neighbor also came. They helped each other, but the relative also went to help.» [DENIA: 4545/6].

Finally, it should be emphasized that on family gatherings, family occasions and more intimate events the neighbor had no longer a place. As the literature writes, neighbors did not speak about the family secrets and they did not have as many rights as the family members. During the holidays, everyone was with their families, with the exception of kántálás and kóringyálás (chanting). Home weddings were also able to accommodate fewer people due to the tighter space.

If we are talking about friends and age groups, we need to mention an important shaping factor in how these groups have evolved from a locality point of view. In the literature, we can read the obvious shaping factors that, based on the principle of locality. Those young people who lived in the same street, one neighborhood, or in the same village part were most likely to meet. In addition, in Hajdúdorog, the ancient divisions of the city into tenth meant a sharp boundary in terms of locality. Which is well exemplified by the following sentence, although it is the opposite, but the informant highlights it:

"We even went to the other tenthof the city to tanyázás (form of visiting each other to have social life between the homesteads), we played cards there and everything.» [DENIA: 4545].

It is difficult to define the boundary of an area, the boundaries of the tenths in Hajdú citites are defined by certain streets. According to the data communicators, in the 1930s and '40s there was still the separation by tenths but this was also the most important limit in making friends between contemporaries. The people who lived in one tenth made friends with each other and chose their partners from each other, from the same tenth part of the city. At this time, the effect of the intersection between the tenths was less, than in the past but passing from one tenth to another tenth was often a risk of physical health or even life-threatening. Each district had a quarter of the city, so big gangs, companionships could come together:

"We went out to swim in the Kerek Lake, we spent a lot of time there, we played a lot of football. (...) They were around the pigs, we bathed in the Kerek Lake, there was the deepest water. Vidito lake only reached the knee. It was in a big area, but we couldn't catch the coot (szárcsa) there, we were chasing it tho and we did things like that, but time passed. When it started in March .., we put our feet in the lake water but there were those who bathed in it already, Miska bathed in it at the end of March.» [DENIA: 4545].

The children of the street played together and were likely to have a narrower locality but the data communication focused on the following: The Levente team, like a Boy Scout, was operating in the city in the 1930s and '40s, where the children were said to be 14 to 16 years old. They studied shooting among other practical things. Due to the central religious situation and the specific culture of the city we must highlight the group of Christ Soldiers who are still operating to this day. They are integral participants in the ceremonies of the Easter Festival. We must mention the Congregation Girls too who carried the picture of Mary during the procession and there were the Bethlehem Groups, which gathered yearly. In addition, at the Sunday Mass, not only in the benches but also in the choir, the young people were able to take their seats in their tenth's place, as the seats were seperated for different tenth divisions, so they didn't mix. To have fun, the young people gathered at homesteads mostly. For the harvest celebration and ball they went to the city. After Sunday Mass, they were able to meet at the promenade (korzó) where the men stood and talked, while the girls enjoyed walking on a particular section of the city. The boys checked the girls carefully for whom they wanted to escort home and then went to talk to her.

Research conclusions. In conclusion, the neighborhood and the contemporary groups can be said to be influenced by the large northern dimension of Hajdúdorog and by the tenth divisions and also by the religious habits. In the case of neighborhood connections, the findings in the literature include a number of elements which are also relevant for Hajdúdorog. These include the community-building role of the neighborhood, neighborhood assistance, daily contact, interdependence, homestead visits (tanyázás), children's play community and the neighborly rights in relation to relatives. Through the studied population an even stronger interdependence can be mentioned as well due to the large size of the homestead land, for example in Northern Szállásföld. We can also highlight that the neighbor played a particularly useful and significant role in the life of the Hajdúdorog population in the first half of the 20th century. On Hajdúdorog, the neighborhood was often more useful than the family. They helped each other in the fields, they lent small assets to each other. The tenth divisions in both neighborhoods and young people influenced their relationship system. This influence on the neighborhoods faded later. In the lives of young people, in addition to literary findings, urban and ecclesiastic-forming factors formed the groups. Examples of this include the Levente Team and the Bethlehem groups.

\section{References}

\section{Sources}

Debreceni Egyetem Néprajzi Intézetének Archívuma, (DENIA)

(Archive of the Institute of Ethnography of the University of Debrecen) 
DENIA: 4545.

DENIA: $4545 / 1$.

DENIA: $4545 / 2$.

DENIA: $4545 / 3$.

DENIA: $4545 / 4$.

DENIA: $4545 / 5$.

DENIA: $4545 / 6$.

DENIA: $4545 / 7$.

DENIA: $4545 / 8$.

DENIA: $4545 / 9$.

DENIA: 4545/10.

DENIA: 4545/11.

DENIA: 4545/12.

(collected by the author)

\section{Literature}

Ballagi, M., 1850. Magyar példabeszédek, közmondások és szójárások gyűjteménye, I-II., Szarvas: Réthy. (in Hungarian).

Bődi, E., 1992. Ünnepi kalács az alföldi néphagyományban. In: Novák, L. (ed.): Hiedelmek, szokások az Alföldön I., Nagykőrös: Arany János Múzeum, 427-442 p. (in Hungarian).

Csete B., 1993. A jászkiséri gyermek élete a születéstől a házasságig, Szolnok: Jász-Nagykun-Szolnok Megyei Múzeumok Igazgatósága és a Jász-Nagykun-Szolnok Megyei Honismereti Egyesület. (in Hungarian).

Fél, E. - Hofer, T., 1969. Proper Peasants. Tradiotional life in a Hungarian Village. (Viking Fund publications in anthropology 46.), Chicago. (in English).

Fél, E. - Hofer, T., 1979. Vázlat a matyókról. Néprajzi füzetek., Budapest. (in Hungarian).

Fél, E., 1993. Tanulmányok Fél Edittől. In: Filemile, Á. - Stefány, J. (ed.): Emlékezés Fél Editre, Budapest: Magyar Néprajzi Társaság, 45-243 p. (in Hungarian).

Giczi, J. - Sik, E., 2009. Bizalom, társadalmi tőke, intézményi kötődés. Tárki európai társadalmi jelentés.

https://www.tarki.hu/hu/research/gazdkult/gazdkult_gici_sik.pdf Downloaded: 26/10/2020. (in Hungarian).

Hoppál, M., 1970. Egy falu kommunikációs rendszere, Budapest: MRT Tömegkommunikációs Kutatóközpont. (in Hungarian). Imreh, B., 1978. Az alsórákosi „sereg”. Népism. Dolg, Bukarest: Kriterion Könyvkiadó, 232-237 p. (in Hungarian).

Jávor, K., 1978. Kontinuitás és változás a társadalmi és tudati viszonyokban. In: Manga János (ed.): Varsány - Tanulmányok egy

Észak-Magyarországi falu társadalomnéprajzához, Budapest: Akadémiai Kiadó. (in Hungarian).

Juhász, A., 1993. Település és közösség, Debrecen: KLTE. (in Hungarian).

Klinger, A., 1997. Magyarország Történeti Statisztikai Helyégnévtára, 11. kötet - Hajdú-Bihar megye. Budapest. Központi Statisztikai Hivatal. (in Hungarian)

Madar, I. Pusztainé, 1989. Fejezetek Zoboralja társadalomnéprajzához, (Folklór és Etnográfia 51) Debrecen. KLTE Néprajzi Tanszék. (in Hungarian).

Márkus M., 1943. A bokortanyák népe, Budapest: A Királyi Magyar Pázmány Péter - Tudományegyetem Magyarságtudományi

Intézete. (in Hungarian).

Molnár M., 1992. The system of social relation within a small local community unit based on tradition. In: Yliaho, Timo (ed.):

Social Networks. The third Finnish-Hungarian symposium on ethnology, Helsinki: Ethnos, 61-70 p. (in Hungarian).

Morvay, J., 1981. Asszonyok a nagycsaládban, Budapest: Akadémiai Kiadó. (in Hungarian .

Nagy Varga, V., 1984. Az emberi élet fordulói. In: Bárth János (ed.): Kecel története és néprajza, Kecel: Kecel Nagyközség

Tanácsa, 897-940 p. (in Hungarian).

Nagy Varga, V., 2000. Mürokonság, szomszédság, kortársi csoportok, barátság. In: Paládi-Kovács Attila (ed.): Magyar Néprajz

VIII, Budapest: Akadémiai Kiadó, 532-552 p. (in Hungarian).

Németh, I., 1966. A népi közösségekben élő fiatalok életmódja és kultúrája. I. Arrabona 8. Győr, 241-263 p. (in Hungarian).

Németh, I., 1980. Leányélet - Legényélet. In: Ortutay Gyula (ed.): Magyar néprajzi lexikon III., Budapest: Akadémiai Kiadó, $417-$ 418, 430-431 p. (in Hungarian).

1949. évi népszámlálás. 1996. Vallási adatok százalékos megoszlása településenként. 3. A népesség vallás szerint, településenként.

Hajdú-Bihar megye. https://library.hungaricana.hu/en/view/NEDA_1949_vallasi_adatok/?query=F\%C3\%B6ldes\&pg=49\&layout=s (in Hungarian).

Ortutay, Gy., 1980. Magyar Néprajzi Lexikon. III., Budapest: Akadémiai Kiadó. (in Hungarian).

Örsi, J., 1984. Kecel népe, mint község. In: Bárth, J., (ed.): Kecel története és néprajza, Kecel: Kecel Nagyközség Tanácsa. (in Hungarian).

Örsi, J., 1990. Karcag társadalomszervezet a 18.-20. században (Agrártörténeti tanulmányok 16.), Budapest: Akadémiai Kiadó. (in Hungarian).

Palotay, G., 1931. A Szécsény környéki palócok „,vendég”-sége. In: Ethnographia XLII, 36 p. (in Hungarian).

Penavin, O., 1981. A nagycsaládszervezet Szlavóniában. (Kórógyon)., Újvidék: Forum. (in Hungarian).

Redfield, R., 1960a. The Little Community, Chicago: University of Chicago Press. (in English).

Redfield, R., 1960b. Peasant Society and Culture, Chicago: University of Chicago Press. (in English).

Sárvári, L., 1996. Vázlatok a magyar görög katolikusok ünnepi szokásairól. In: Küllös Imola (ed.): Vallási néprajz. VIII.

Ökumenikus tanulmányok., Debrecen: Református Teológiai Doktorok Kollégiuma Egyházi Néprajzi Szekciója, $203-217$ p. (in Hungarian).

Sik, E., 1991. Néhány adalék a háztartási kapcsolatrendszerek múködéséhez - egy magyar falu esete. In: Utasi, Á., (ed.): Társas kapcsolatok, Budapest: Gondolat Kiadó. (in Hungarian).

Szabó, L., 1982. A jász etnikai csoport II., Szolnok: Damjanich János Múzeum. (in Hungarian).

Tárkány Szücs, E., 1981. Magyar jogi népszokások, Budapest: Gondolat Kiadó. (in Hungarian).

Tátrai, Zs., 1994. Leányélet, Budapest: Crea Print. (in Hungarian).

Ternovácz, I., 1996. Pusztulj, kulák!, Budapest: Hatodik Síp Alapítvány. (in Hungarian). 
Tönnies, F., 1983. Közösség és társadalom, Budapest: Gondolat Kiadó. (in Hungarian).

Vankóné Dudás, J., 1983. Falum Galgamácsa, Szentendre: Pest megyei Múzeumok Igazgatósága. (in Hungarian).

Vasas, S., - Salamon, A., 1986. Kalotaszegi ünnepek, Budapest: Gondolat Kiadó. (in Hungarian).

Viski, K., é. n. Drámai hagyományok. In: A magyarság néprajza. III. Budapest: Királyi Magyar Egyetemi Nyomda. 327-371 p. (in Hungarian).

\title{
SUMMARY
}

\section{СУСІДСЬКІ ТА СУЧАСНІ ГРУПИ В ЗАМКНУТОМУ СУСПІЛЬСТВІ В ХАЙДУДОРОЗІ}

\author{
Томаш Шарі \\ аспірант докторської школи історії та етнографії, \\ гуманітарний факультет, Дебреценський університет, \\ Дебрецен, Угорщина
}

\begin{abstract}
Хайдудорог - ие місиеве закрите суспільство, тому релігійне відокремлення, військове минуле Хайду та сільськогосподарський характер поселення забезпечують специфічний підхід до етнографічних досліджень. У моєму докторському дослідженні, яке включає иฺю статтю, у изьому населеному пункті аналізуються стосунки сім'ї та сусідства. Часовий фокус дослідження - 1940-ті роки, що є найранішим десятиліттям, яке можна досліджувати разом з інформаторами за допомогою інтерв'ю. У иій статті звертається увага на сусідство Хайдудорога та сучасних груп, тому місцевість є ключовим поняттям. Дослідницьке питання стосується змісту відносин. Як відносини в оточенні сусідства та сучасних груп проявились у Хайдудорозі в 1940-х роках? Як вищезгадані функиї вплинули на цее? Дослідження проводилося в рамках етнографічної дисиипліни. У статті спочатку подаються відомі твори угорської етнографічної літератури на цүю тему, а потім аналізуються емпіричні дані. Я застосував етнографічний метод, щз використовується в суспільних дисциплінах, для отримання емпіричних даних. Під час польових робіт я робив інтерв'ю в Хайдудорозі з місцевими жителями, віком старше 75 років. Я звернувся до суб'єктів співбесіди за методом снігової кулі та інтерв'ю, яке відбувалося вдома у респондентів. У статті окремо досліджуються сусідні та сучасні групи. На підставі результатів можна констатувати, що в Хайдудорозі добросусідські стосунки були щоденними. Десяті, колишні спеціальні адміністративні одиничі міста, були ще сильними чинниками впливу на розвиток відносин в обох групах навіть протягом досліджуваного періоду. Зміст сусідських відносин знайшов відображення у дрібних господарських операчіях, оренді знарядь прачі, участі у забоях свиней (disznóvágás), допомозі в польових роботах, особливих народних забавах (tanyázás), щзо призвело до інтенсивніших стосунків, ніж з родичами сім'ї. Результатом закритого суспільства стали тісніші стосунки між тими, хто проживав в одній частині населеного пункту, ніж між родичами, які жили в різних частинах поселення. Відповідно до вищесказаного, стаття прагне внести свій внесок у дослідження, пов'язані з місиевістю. Тема статті вписується в категорію соціологічних досліджень сусідства, таких як дослідження Тонніса та Редфілда, а також у дослідження околищь угорської етнографії, що також було базою для цььго дослідження. Ця робота сподівається в кінцевому підсумку розширити ряд літератури Гайдудорога. Для подальшого перегляду, ия стаття може заохочувати дослідження, які стосуються більи детального порівняння ролі сусідства та ролі сусідів та родичів у Гайдудорозі протягом періоду, який розглядався у ичій статті.
\end{abstract}

Ключові слова: околиці, місцевість, Хайдудорог. 